\title{
Opening up the Economy of Turkey to the Outside World: The Stabilization Decisions of January 24th 1980, Economic Situation in pre and Post January 24th Period
}

\author{
Karluk Sadik Ridvan, Küçüksakarya Sevilay \\ Anadolu University, Eskişehir, Turkey
}

\begin{abstract}
As a result of the fact that the stabilization program put into force in 1978 and 1979 in the Economy of Turkey could not be efficiently implemented due to the political instability and weak governments, a need to draft a new stabilization program emerged. The stabilization program of January 24th, 1980 was prepared in this environment. This is a program which includes the structural transformations in the long term as well as the aims foreseen to be realized in the short term. The program adopted the implementation of significant changes in the structure of the economy and the price mechanism in the market which becomes the only guide as the basic principle. The difference from the previous programs is an economic development program intending to provide a very permanent and structural change in the economy rather than to realize the short-term goals. With the decisions, a large devaluation was implemented, the exchange rate policy and importation were liberated, foreign capital and exportation were encouraged, the subsidies with the exception of energy, fertilizer, and transportation were removed, restrictions were imposed on the support purchases in agricultural products, and the overseas contracting services were supported. There are two structural objectives desired to be performed in the long term, shrinking the public sector and removing the intervention in the markets. The basic philosophy is to decrease the state intervention to the minimum level in the economy and to bring functionality to the market economy and to validate the price mechanism. In this paper, the stabilization decisions in the economy of Turkey belonging to pre- and early post-January 24 th period will be comparatively analysed.
\end{abstract}

Keywords: The Decisions of January 24th, 1980, Turgut Özal, Süleyman Demirel, export-oriented industrialization policy, the decisions of February 4th and April 5th 1994

\section{Introduction}

In global economy, many stabilization programs have been applied in order to overcome the inflationary instabilities and crises. Since they ruin the economic stability, the crises should be solved. A crisis is a severe fluctuation in goods, service, and foreign currency markets or production factor, beyond the reasonable variation level (Kibritçioğlu, 2015, p. 504). In theory, the crises are divided into two major groups as: real sector and financial crises. The real sector crises occur with the severe fluctuations in goods, services, and labor markets. On

Karluk Sadik Ridvan, professor (retired), Department of Economics, FEAS, Anadolu University, Eskişehir, Turkey.

Küçüksakarya Sevilay, assistant professor, Department of Economics, FEAS, Anadolu University, Eskişehir, Turkey.

Correspondence concerning this article should be addressed to Karluk Sadik Ridvan, Department of Economics, FEAS, Anadolu University, Eskişehir, Turkey. 
one hand, in these sectors, if the prices increase rapidly (inflation) or there is shrinkage in employment (unemployment) that means there is a crisis, on the other hand, financial crises are money, banking, systematic financial, and foreign debt crisis. The countries should apply stabilization programs to avert these crises.

The money crisis occurs when the State authorities take measures in order to protect the national currency. In such case, effected by the speculative attacks, the State authorities increase the interest rates and in a considerable extent spend the international reserves which cause the devaluation or loss of value of the national currency. In the first case, the banks become unable to perform their liabilities or they bankrupt. In the second case, in order to prevent the banking sector crisis, the State interferes and increases the aid for banks. The financial crises are shocks that lead to interruption in major functions of the system such as: credit allotment, payments, and asset valuation. These crises may include money crises but money crises not necessarily lead to systematical financial crises. The foreign debt crises occur when the country shall not be able to pay its public and private foreign debts.

The policies to prevent crises-accordingly the instabilities are classified as orthodox and heterodox. The basis of these policies is the reduction of the factors that cause the excessive demand in economy. The essential condition of these policies is the economy agent's trust. In the heart of these policies, there are strict monetary and financial policies. The decline in the real income, decrease in the total demand, shifting of the economic burden to the fixed income groups and small business, controlling of the nominal money amount, and restrictions in public spending are the major properties of these policies. The orthodox policies are supported by IMF.

The orthodox stabilization programs are implemented to recover the foreign balance and decrease the inflation. For this purpose, the reduction of the real wages is predicted and the liberation of prices is recommended. In order to stabilize the prices, by using the monetary tools, the national currency is chosen as an "anchor". For this purpose, the discipline in public finance and the implementation of strict monetary policy are needed. As a result of the implementation, the decrease in growth rate, reduction in industrial production, increase in unemployment, recession, and deterioration in distribution of income are against the people with fixed income occur.

It is hard to implement such a stabilization program in democratic countries. Though, in these countries, the governments shall refrain from financial and structural reforms. Belt tightening policies cause loss of votes. In that manner, the implementation of such stabilization programs is easier to fulfill in countries having authoritarian - martial administration. In contrary, when implemented in democratic countries, these policies become unsuccessful and the governments that implement this type of stabilization program had to resign (Karluk, 2015, pp. 478-479).

Usually, the heterodox stabilization policies are implemented in countries where the inflation is permanent. In implementation of these policies, with the public reconciliation, the increase in the wage, interest, and exchange rate is frozen, also the income policy is implemented. Different from the orthodox policies, the target of heterodox policies is to reduce inflation in a short term, without causing any decline in production and employment (Kiguel \& Liviatan, 1991). The freeze on wages and prices interrupts the short term wage price spiral. The most important issue of the countries which are experiencing high inflation and implementing a stabilization program is the nominal anchor. In addition to the policies implemented under the stabilization program, inflation control is provided by controlling one or more of the relative prices (exchange rate, wage, interest) (Bahçeci, 1997, p. 48). 
The continuation of the existence of inflation is important in effectiveness of the policy. Hence, the pessimism of the society resulting from the unsuccessful stabilization program affects the success chance of the policies. In that sense, a stabilization program should be credible and consistent. In such a case, the freeze of prices, wages, and foreign exchange rates should be an indicator of change of policies (Esen, 1989, p. 34). Under the conditions of hyperinflation, the economic units would think that the future inflation rates would be equal to the past inflation rates and expect a higher rate of inflation in the following period. Thus, the hyperinflation transforms into an infinitive spiral and pessimism occurs in the society. In short term, the freeze of prices and wages in economy breaks the expectation of inflation and those results in case of wage spiral, and increases the credibility of the stabilization program upon society. The hyperinflation starts when the monthly inflation becomes over $50 \%$ and finishes when it continues under 50\% during one year. In Turkey, during the Republic period, hyperinflation has not been experienced; however, there have been chronic inflation periods that high inflation rates were experienced

The heterodox stabilization programs are implemented as shock treatments (heterodox shock) against inflation (Helpman \& Leonardo, 1998, p. 28). It is hard to avoid the implementation of shock policies when high inflation moves towards hyperinflation. These programs have four major sources. These are the freeze of prices and wages targeting the avert of the rise of inflation, the application of financial discipline to fix the exchange rate, the prevention of the budget deficits and in order to support those mentioned, and the implementation of strict monetary policies (Cin, Yalçin, \& Doğru, 2000, p. 66). After 1985, to decrease the high inflation in Argentine, Brazil, Mexico, and Israel, classical stabilization policies together with income policy have been implemented (Dornbusch, 1992, p. 25). For the policies to be successful and can reach their goals, the society should support them, beside, the country should be given a foreign support. In order to be successful in implementation of these programs, it is not enough to freeze the prices, also the monetary and financial policies should be adopted to balance the existing imbalance. In that point, the problem is the scarcity occurring in goods market following the freeze of the prices. That causes the black market.

The superiority of the heterodox programs is the lesser unemployment. In medium and long term, the control of prices may cause deterioration in relative prices. This situation results in disruption of effectiveness of market mechanism (resource allocation). In that manner, in long term, the freeze of prices and wages should be abandoned. However, it is hard to say that resource allocation is effective in an environment of three digits inflation.

Another key to decrease expectation of inflation in heterodox policies is the importance of stabilization. This key is the anchor of the stabilization program. In order to prevent the ships to drag over the sea, an anchor is thrown into the sea. The ship may float around the anchor but it would not drag and it will finally stabilize. Since they believe that it endures and supports the anti-inflation implementations, some writers claim that instead of the word "anchor", the word "support" should be used (TIM, 1996, p. 91). Some writers defend the use of "hook" instead of anchor. It has been chosen the term "anchor" in this presentation. In theory, the stabilization programs are also classified depending on the anchor chosen. The "exchange rate", "interest rate", "money supply", "bank credits", or "wages and payments" could be chosen as an anchor.

In heterodox stabilization programs, freeze of exchange rate has been prominent to reduce the inflation expectation. In applying this policy, currency is used as an anchor. By fixing the country's currency exchange rate with a chosen foreign currency, the connection between the real value of the country's currency and surplus of currency demand is disconnected. This policy may cause a negative effect on international trade and payment 
balance to a positive real value in local currency. In order to prevent this effect, a strong foreign financing is needed. This necessity will grow in proportion to the degree of economy's foreign expansion. The stabilization program, based on the currency exchange rate, is usually implemented in countries having high inflation. The cost of this policy is lower in situations where the economy comes to a point of pause. In economies where the inflation is mild, the stabilization program's possibility of decreasing the price increase is quite low (Dornbusch \& Fisher, 1993, pp.1-44).

The programs in which the money supply is increased appropriate to the rate of targeted inflation are named as money base stabilization programs (money base stabilization) and the programs in which the exchange rate is increased appropriate to the rate of targeted inflation are called exchange rate stabilization programs (exchange rate stabilization) (Wijnbergen, 1987, p. 5). The implementation of the exchange rate based programs is based on the purchasing power parity (PPP). If the exchange rate is designated based on the PPP, the speed of increase of prices of goods and services in foreign trade would be equal to the devaluation rate (Yazgan \& Akay, 2000, pp. 49-50).

In Turkish economy, with the Stabilization Decisions given on 5th April 1994, the anchor was chosen as exchange rate with two reasons: to decrease the inflation increasing effect of devaluation and to create the stability to attract the foreign capital. A pyramid scheme is established when hot money enters into the economy with the result of high real interests combining with slow depreciation of exchange rate. Hence, the high interest rate-low exchange rate creates an arbitrage profit that causes a loss in credibility of the stabilization program.

In countries, having chronic inflation not reaching to the hyperinflation level, the stabilization program that is implemented is named as "gradual stabilization program". In this kind of stabilization programs, in addition to the targets, there are targets of disciplining the public spending and decreasing the gaps in the balance of payments. In gradual stabilization programs, in addition to the major targets, the intermediary targets are also important. In the program, while the major target is reduction of budget deficit, the intermediary target is the reduction of interest payments in the budget (Uygur, 1993, pp. 23-24).

\section{The Economic Situation Before the 24th January 1980 Dated Stabilization Decisions}

After the middle of 1970s, the Turkish economy had become distant to the "period of progress". The period of progress is the period between the years of 1963-1970 that progress with stabilization occurred (the medium of growth rate $6.5 \%$, the average yearly inflation rate of 5.5\%). The period between the years of 1971 and 1977, the yearly inflation rate passed over $18 \%$. In the first half of 1970 s, the increase in world oil prices has not been reflected to consumer's price and the difference has been paid by the Treasury. On 01.01.1970, one barrel of oil was 1.80 USD; on 15.02.1971, one barrel of oil was 2.18 USD; on 01.01.1973, it was 2.59 USD; on 01.06.1973, it was 2.90 USD; on 01.10.1973, it was 3.01 USD; on 16.10.1973, it was 5.12 USD; on 01.01.1974, it was 11.65 USD; in 1977, it was 13.8 USD; in 1979, it was 18.1 USD; and in 1980, it became 33.0 USD. In year 1981, the yearly average crude oil price increased to 38.1 USD and in year 1986 it decreased to 15 USD. It has fluctuated between 15.2 and 23.6 USD in the period of 1987-1997, but in year 1998, it has decreased to 12 USD. The price in 2001 was 22.7 USD. In December 2003, price was 28.4 USD. Although in December of 2004, the oil price was 35.4 USD in August 2005, a barrel of oil (One barrel = 159 liters) has made a peak of 70 USD.

After the world oil shock, Turkey's cheap energy policy based on oil, bankrupted. In 1972, while the rate of oil and oil product importation was $10 \%$ of total importation of Turkey, this ratio was $20 \%$ in $1974,21 \%$ in 1976 , 
$30.5 \%$ in 1978 , and raised into $47.1 \%$ in 1980 . In years of 1978 and 1979 , because of the scarcity of foreign currency, the importation of oil had been restricted and that caused stagnation in economy. The increase in oil invoice also caused the scarcity of foreign currency. That caused the international trade to return to bilateral agreement markets rather than free markets, which turned the international trade against the country. Since the external deficit, arising out of the foreign trade deficit, increased the demand of credit, there has been a high increase in the deposits convertible into foreign currency. The total of short term external debt in 1975 was $24 \%$. However, after two years, it has doubled into $58 \%$. The rise in the short term external debt also increased the inflationary pressure.

After the second half of the year 1970, the gap between the public income and public expenditure started to be recompensed with borrowing. While the Public Sector Borrowing Requirement/National Income (PSBR/GNP) rate was $2 \%$ between the years of $1972-1974$, it was $6.6 \%$ in between years of $1974-1976$, and rose to $9 \%$ between years of 1977-1979. The public deficit increased because of the budget deficit and Public Economic Enterprise (PEE) losses. While the PEE losses had been 52 billion Turkish Lira (TL) in 1978, after two years, the losses reached to 62 billion Turkish Lira. The burden of 1974 Cyprus Peace Operation had an important effect on the budget deficit. The arms embargo applied by USA to Turkey following the operation should also not be forgotten.

The bottleneck of energy and foreign currency that occurred in the second half of 1970 s caused the decrease in production in industry sector. The Gross Domestic Product (GDP) and factor prices decreased in years of 1979 and 1980. The GDP which was 47.5 billion TL in 1978 decreased into 42.5 billion TL in year 1980. In addition to these negative developments, after the second half of 1970s, the inflation became higher and the foreign currency shortage increased. While, the wholesale product index was $52.6 \%$ in 1978, it has jumped into $63.9 \%$ in year 1979. After 1977, the foreign currency shortage created serious problems in economy, and with the words of back then Prime Minister Süleyman Demirel; Turkey became a country in need of "70 cents". The "70 cents" statement created a misunderstanding so it would be good to describe the situation in his words. In a letter Demirel wrote to Emin Çölaşan, he explained his words as:

The second misunderstanding is the issue of "Cent". The "70 Cents" issue is this: in year of 1977 in the season of hadj, 136 thousand people were given the opportunity to go to hadj. This number was one of the biggest numbers for many years. Even the country was experiencing many aforementioned problems, one of the fard (religious duty) worships the "hadj" opportunity had been provided to Turkish citizens. I should state that I really care about this issue. A duty befitting to the State has been performed. However, new requests kept on coming, especially the bus companies lead the requests. The answer we have given to those were: "Although our country is need of '70 cents', our State has spent 70 million for this service". Please appreciate it and do not request for more, this was an issue of wording, a style of statement. (Karluk, 2014, p. 516)

The 9th President Süleyman Demirel, in one of his press statements stated that "Presently, we are not in need of 70 cents but one cent". In that matter, he made the following explanation:

The third misunderstanding is: the one Cent issue. Since its establishment one of the most important issues of Turkish Republic has been the balance of payments. The foreign currency income of Turkey is fatal. In that purpose Turkey will move towards the industrialization. The first condition of industrialization is electricity, the second condition is transportation, and the third condition is capital and technology. In 1965 Turkey's foreign currency income was 450 million USD, in year 2000 it is 45 billion USD. It is 100 times more. Nevertheless, the foreign currency need of Turkey could not be satisfied. Any country, satisfying its need for foreign currency with borrowing is in need of one cent. This is what it has been tried to be told. (Kumcu \& Pamuk, 2001, p. 122) 
In year 1977, the Convertible Deposits (CP) could not have been paid and in year of 1978 the foreign debt increased to 4.8 billion USD, 1.4 billion USD portion of the foreign debt was CP and 1.5 billion USD part of it was the debts arising out of the imported goods. Following the year 1970, the price stabilization deteriorated and the yearly inflation passed over 18\%. As a result of general deterioration in economy, in April 1978 and March 1979, the governments have put two similar stabilization programs in force. To be successful in implementation of the stabilization programs, the foreign support was a necessary, so International Monetary Foundation's (IMF) support was needed. In order to realize that, a letter of intent had to be submitted to IMF and a stand-by arrangement with IMF had to be organized. The stand-by arrangement is defined as an agreement by some authors. However, the right wording is "arrangement". Although the stand-by arrangement is a contract, in which the Member State signs and accepts the conditions of the found, based on international law, it is not an agreement (Karluk, 2014, p. 565).

In order to have an approval of the IMF stand-by arrangement, the country should submit a letter of intent to the IMF, which is a covenant, including an economic program with series of measures that will be taken. To facilitate that, several meetings with IMF teams of three to four members take place for one to three weeks and the program is prepared. Following that, signed by the Head of Central Bank and Minister of Finance of the country, the letter of intent is sent to IMF administration.

If IMF Executive Board approves the letter of intent, the country will be financed. In practice, the letter of intent is prepared by IMF administration and then the country's government approves it. The countries which submit letter of intent to IMF, accept to open their economic policies to the review of IMF, they also guarantee to not to act against the goals set forth in the letter of intent and approve that their economies are periodically audited by IMF technical teams.

The financing that is provided with the stand-by arrangement covers a period of 12-18 months of support of economic program. In order to have the financing, the country should prepare a stabilization program. The program includes the following: The liberalization of prices, freeze of wages, a significant (a high rate) devaluation, tax reform, equal budget, restriction in public spending, privatization of State Owned Enterprises to decrease the number of employees, etc. There is an important message in approval of the loan of IMF which is that the country's program is confirmed and western banks can provide loans to the country with thrust.

There is a quota called Special Drawing Rights (SDR) of each member state in IMF (Karluk, 2013, p. 818). Financing is provided to each Member State based on their quota and the strength of their program. Since the program approved by IMF disciplines the economy, it is impossible for the country to apply a free economic policy. However, as a result of the domestic pressure, the countries deviate from the IMF policies. In that case, IMF cancels the arrangement and the issue gets more complicated. The success of the country that declares the stabilization program depends on the implementation of the program by making no concessions (Alkan \& Bahçekapili, 1998, pp. 48-61). Joseph Stiglitz who is the consultant of USA Presidents has made the following statement when he came to Istanbul in 2004 "Being in a very close relationship with IMF is dangerous, the farther your relationship with IMF, the better your relationship is" (Karluk, 2014, p. 573).

Before 1980, the target of stabilization decisions taken in years of 1978 and 1979 was to provide the foreign balance. Thus, the reason of economic recession intensifying after the second half of 1970s was the deficit in the payment balance arising out of the foreign currency scarcity. The other targets were reduction of inflation and recovering of losses of State Owned Economic Enterprises (SOEE). As a result of the decisions taken, the Turkish Lira devaluated against USD at a rate of $23 \%$ in year 1978 and $28.6 \%$ in year of 1979. 
These decisions include the following measures: a high rate of increase in SOEE product prices, bringing restrictions to the emissions increase, restriction of imports, support of exports; bringing discipline to the public spending, increase of interest rates, the decrease of development speed by decreasing the investment spending, narrowing the capacity of agricultural product support purchasing, ending the $\mathrm{CP}$ implementation; and bringing restrictions to the increase in wages of employees and in prices. If these measures were applied successfully, 640 million USD would be loaned for 1978 Program and 1.8 billion USD would be loaned for 1979 Program and the foreign balance would be realized.

The 1979 and 1978 Stabilization Decisions could not have been implemented persistently because of the political instability in Turkey. As a result, only a few foreign credits have been used. The wages and payment could not be restricted, the public spending could not be reduced, increase in tax revenues could not be realized and the budget deficit could not be closed. In addition, the high supportive prices were financed by Central Bank. That fueled the inflation and the inflation raised above $80 \%$ in December 1979. While the prices were increasing, as result of the scarcity of foreign currency, the imports were restricted. The energy shortage caused the usage capacity in industrial sector below 50\% (Boratav, Keyder, \& Pamuk, 1984, pp. 15-25; Boratav, 2010, pp. 1-28).

In September 1977, March 1978, and June 1979, a high rate of devaluation has been made. The currency guaranteed in Convertible Deposits was cancelled. Also in order to increase the foreign currency savings, restriction to the foreign trips has been applied. The total foreign debt especially the short term foreign debts increased with the effect of non-guaranteed commercial debts against goods. The inflation and payment balance deficit has become the highest in Republican history. In summary, the implementation of the 1978 and 1979 dated Stabilization Decisions has not been successful because of the conditions of that period and their lack of any integrity (Kuruç vd., 1987, pp. 1-266; Parasiz, 1998, pp. 1-73; Akalin, 2002, pp. 1-71).

The letter of intent prepared by Ziya Müezzinoğlu, the Finance Minister of Bülent Ecevit government in 1979, could not be implemented as a result of resignation of Ecevit government on 16th October 1979. On 30th of June 1979 dated letter of intent, Turkey was requesting a new supporting arrangement. In the letter, it was emphasized that: in the past, the crises occurred because of the implementation of mistaken economic policies. It was also stated that, the internal savings would be increased, the pricing policy of SOEE would be more elastic and the public investment would be shifted to more critical areas. In addition, it was stated that an extensive tax reform would be implemented and arising out of the increasing debt service load, the difference between import and export might increase.

In the letter, it was explained that, the advance payments of Central Bank had been restricted to some level, the number of public officers and workers had been frozen, savings in SOEE had been applied. Also it has been emphasized that in order to reduce the internal demand, the raises had been kept high to restore the balance of credits and savings, the banking interest rates had been increased by 5.5 points. It is also stated that the payment of debts would be made without delay to build the trust and if the measures taken by the government would not be satisfying, additional measures would be taken and consultation of the IMF would be requested for this purpose. As a result of these commitments in July of 1979, Turkey got 256 million SDR financing from IMF.

The commitments in the letter of intent was submitted to IMF on 2nd of June 1980, which was prepared by Ismet Sezgin, the Finance Minister of the government of Süleymen Demirel minority government obtained a vote of confidence in the Parliament on 25 November 1979 were; the difference between the speed of inflation 
and the speed of inflation of the countries which Turkey is in trade relations, would be recovered with devaluation, the increase of costs of public spending would be reflected in prices, the number of state officers would not be increased more than 3\%, the increase in state officers salary would not be more than $47 \%$. Also it was stated that an agreement on the issue of Central Bank credits and internal assets size would be made with IMF. Turkey, on the date of 18th June 1980, has signed a new arrangement which was 1.250 SDR in value for three years. The IMF arrangement supporting the 24 January Decisions continued until 1983. In year of 1985, the back then Prime Minister Turgut Özal had a meeting with IMF Director Jacques de Larosiere and stated that Turkey is not in need of any more support arrangements. Hence, Turkey had eluded its bindings to IMF for a period of 10 years. This situation continued until back then Prime Minister Tansu Çiller had a meeting with IMF Director Michel Camdessus (Ertuna, 2001, pp. 491-510; Turan, 2011, pp. 56-80; Eğilmez \& Kumcu, 2013, pp. $1-34)$.

\section{4th January 1980 Dated Economic Stabilization Decisions}

In the beginning of 1980, Süleymen Demirel who established the minority government has appointed Turgut Özal as the Finance Minister to lead the economy with the full authority. With the leadership of Özal, a stabilization program called the 24th January Decisions which have dominant neo-liberal quality been prepared. The monetarism approach representatives of the neo-liberal opinion are Friedrich Augustvon Hayek and Milton Friedman. In this approach, the only way to prevent inflation is to control the supply of money. The implementations that should be performed are reduction of State interference in economy, implementation of market economy by not interfering to the supply demand balance, and leaving higher funds in the hands of private sector by decreasing the taxes.

The Decisions have been implemented until 12th September by Süleyman Demirel minority government and until December 1983 by the military government. On 13th December 1983, when Motherland Party which defends more liberalization in economy came to power, the architecture of 24th January decisions Turgut Özal, as also having the political power, kept on implementing the program with additional measures. The decisions with its additional measures put in effect later, have paved the way for Turkish economy to have an important place in the world presently. The stabilization decisions implemented before and after 24th January have the qualifications of both the heterodox and orthodox stabilization programs.

The program has long and short term targets. Its difference from the previous programs was that the program was a program of economic development targeting structural changes in economy, other than implementation of short term targets. The programs implemented before 1980 were having short term targets and include decisions not having liberal feature. In short term, it targeted the resolution of foreign debt payments, reduction of inflation speed, and increasing the development speed by prompting idle capacity. The long term target was narrowing the public sector and restricting the interference to markets.

The targets of the Decisions were integration of Turkish economy to global economy, reduction of State interference in economy, utilization of market economy, and validation of pricing mechanism. In line with this philosophy, removal of interference to goods and factor prices, increase of the effect of free market powers, narrowing the public sector and giving weight to private entrepreneurs, the liberation of imports, giving incentives to exports and foreign capital, procurement of price competition in economy, restriction of interference to markets, cancellation of foreign currency controls, and integration of the economy to global economy were targeted. 
Together with the Decisions, the liberalized policies were started to be implemented, so import-substitution industrialization which had been applied has leaved and export-oriented industrialization policy has been adopted. A series of measures to remove the barriers of international expansion of economy have started to be implemented (Karluk, 2010, pp. 1-3).

After the 24th January Decisions, Turkey started to implement export-oriented industrialization policy. In that manner, the comparative advantages (Karluk, 1981, pp. 3-15; Çarikçi, 1983, pp. 1-9) were reviewed and the sectors of textile, construction, and light industry were chosen as the locomotive sectors. As a result of the decisions, the exports increased and the share of industrial goods increased in exports (Dibooglu \& Kibritcioglu, 2004). With the realistic exchange rate, real interest, and liberal foreign policies, the imports increased to 5.7 billion USD in 1983, from 2.9 billion USD in 1980 (Karluk, 2014, p. 619). The share of imports in national income reached to $16 \%$ in 1987 from 3.4\% in 1979. The imports reached to 10 billion USD in 1987 from 2.2 billion USD in 1979 (Tokgöz, 2001, p. 193).

As a result of the increase in imports and foreign currency income, the payment balance deficit narrowed, the foreign currency bottleneck widened, foreign capital, workers foreign currency, and tourism income increased. The foreign financing enabled with the new credits provided by the international markets. After the 1981 liberation, since the imports increased in a high speed, the foreign trade deficit increased. The energy shortage resolved and the rate of capacity used in economy increased. The prices, especially in the year of 1980, have rised to three digits in republic history and decreased after 1981. In the period between 1981 and 1987, the prices continued on yearly average of $30 \%$. The criminal measures over the gold and foreign currency ended, the stock market developed and after 24th of January, all the tools of the money market gained its place in the economy.

On 1st of July 1980, the interest rates are liberalized. However, in July 1983, the system re-organized and the banks are regulated. After August 1983, Central Bank has been given the duties of controlling the deposit interest rates and designation of base interest rates. On 1st of May 1981, daily foreign exchange rate implementation has been started to be applied, the subvention on fertilizers, energy, and transportation has been removed, and agricultural support purchases were restricted. The base prices of agricultural products decreased to reduce the inflation pressure. As a result of this, internal terms of trade developed against the agriculture sector and the income portion of the farmers decreased.

On 30th July 1980, Capital Market Law came into force. In 1981, the Capital Market was established. In 1982, permission was granted to open a foreign currency account, within the period of 1983-1984, the foreign trade and foreign currency implementations were liberalized. In 1985, Central Bank public bond tender started, the stock market opened in 1986, Central Bank opened Interbank money market and in 1987 open market activities started (Uludağ \& Serin, 1987, p. 146; Ekzen, 1984, p. 180; Şenses, 1981, p. 417). Against these positive developments, the growth rate was not enough, the unemployment increased, the role of the state in economy could not be reduced, the social injustice grew, the distribution of income deformed, the implementation of extra budgetary fund surged, the tax income of the state has not increased in line with growth rate, the budget deficit firstly decreased but then increased as a result, and the public deficit increased.

After 1980, the primary measures designated under the IMF stabilization program which was put in effect in three years were: the reduction of money supply and public spending, the liberation of interest rates, high devaluation of Turkish Lira, reduction of budget deficit, giving the right to increase of prices of its products to State Owned Enterprises to satisfy the demand in their products, reduction of subvention, the reduction of price 
control, and implementation of measures to speed up the foreign capital investments. Also providing support to the industries of exports and continues support to the exports (tax and easiness in use of loans) were other measures designated in the stabilization program.

After the 24th January Decisions, the measures that minimize the State's place in economy were continued to be taken. The cigarette monopoly has been ended, privatization activities of the SOEE have been started, the laws of expropriation of mines annulled. In this context, the Pricing and Auditing Committee ended its activities and SOEEs were given the right to designate their product prices. The incentives to foreign capital investment were given, convenience for the transfer of profit was enabled and support was given to the foreign construction services. Tax returns, loans with low interests, the customs exemptions for producer exporters, and the incentives system for different sectors and exports were supported. However, the CP implementation was cancelled.

The period of 1981-1988 can be named as the first stage of liberation program of Turkey. In these years, the incentive policies for exports, the direct, and foreign currency exports subvention tools were used (Hakan, 2000 , p. 44). The second stage has started with the freedom of capital inflow. The regime of foreign currency has been liberalized with the 32 numbered Decision given in 1989 as well as the movement of capital. Some of the economists interpreted this situation as opening the capital movement item of the payment balance to international finance capital's speculations (Yeldan, 2003, p. 2; Boratav, 2010, pp. 1-31).

After the 1980 Decisions, even Turkish economy has entered into a structural change phase; the Decisions could not accomplish a perfect success in needed stabilization of the economy, so in 1988, the economy faced a new crisis. However, this crisis was different from the ones before the year 1970. In the beginning of 1988, although the prices increased, the production decreased, while the real investments decreased, a tendency of investment occurred in sectors not subject to international trade, while the real wages decreased and the interest rates increased. In addition, the public deficit increased, current account deficit balance of payments had a surplus.

In the period of 1986-1988, the revival in economy is followed by a slowdown, which caused the crisis. The pricing of public products below their costs, increased the public deficit and that caused inflation. As a result, flight from the Turkish Lira has started. In order to prevent this situation, at the end of the year 1987, a high increase of the prices of products of SOEE had been made. As a result of decrease in the internal demand, the exports increased. Because of the increased interest rates, the costs increased. In order to recover the deficit in public, the public investments were restricted. This has negatively affected the private sector production and investment. The environment negatively affected the financial markets. The demand of foreign currency increased and flight from the Turkish Lira has started. The high valuation of TL increased the short term capital (hot money) inflow to the country with the liberalized capital movement.

\section{Situation After 24th January: The 4th February Decisions}

The development and change that have been realized with the 24th January Decisions have continued the general elections in 1987. With the effect of the elections, the public deficit increased, the balance in financial markets disrupted, the interest rates, and the foreign exchange difference increased. The foreign currency reserves decreased and the foreign debt became unpayable.

In this environment, on 4th of February 1988, the government has taken several Decisions to prevent the crisis. The implementation of transfer of foreign currency to the Central Bank by banks has started and the deposits interest was liberalized. In those years, when the interest rates were liberalized, the interest rate was $65 \%$. 
The race of interest rates continued for two to three days and the interest rates reached to $120 \%$. By interfering to the one-year-deposit interest rate, it has been restricted to $85 \%$ and the crisis has been recovered by not giving too much damage to the system. In a sense, the interest crisis was beneficial to the Turkish economy to settle some of its balances. In the Decisions, reduction of inflation to $10 \%$ in three years was targeted. After the Decisions, the economy stagnated and inflation increased. At the end of the year 1988, inflation reached to $70 \%$ from $50 \%$, the velocity of growth rate decreased to $1 \%$ from $9 \%$, conversion to TL from foreign currency started and the velocity of foreign currency entries from abroad got higher. The foreign currency's open position in banking sector has started in those days.

The indicators related to the economy before and after the Decisions are as follows: January 1st, 1988: one USD was equal to 1.018 TL; January 29th, 1988: one USD was equal to 1.113 TL; February 10th, 1988: one USD was equal to $1.143 \mathrm{TL}$; January 1988, the average interest was $40 \%$, the bank liberalized interest rate was $120 \%$, Istanbul Stock Exchange Index was 3.62, the foreign currency reserve on 5th of February 1988 was 1.5 billion USD. The raise of interest rates to prevent the escape of hot money from the country reduced the production in the country. The stagnation in economy increased because the decrease in growth of agricultural sector is caused by the drought. The industrial production was stimulated with the increase in consumption expenditure with the raise given to wages and salary in the rate of $200 \%$. As a result of these, in 1990, the growth rate became the highest in last 20 years. However, the stabilization program has not been implemented. While these were happening in the economy, because of the February 4th Decisions, Mother Land Party lost lots of votes in local elections, and the MP's popularity declined.

The monetary policies eased off because of the 1991 early election, the political instability (Kibritçioğlu, 2001, pp. 174-182) and the break out of 1990 Gulf Crisis. The early general election caused the expansion of support purchasing which has been applied only to 199 products, the increase of prices and wages of public workers, so the public deficit increased. As a result, the PSBR and GDP rates increased. The 1990 Gulf War initiated the withdrawal of deposits from the banks which caused a new crisis in banking sector. The pressure on the Central Bank amplified with the increasing spending early election. These developments disrupted the balance in economy and prepared the environment for the increase of foreign currency exchange and interest rates.

After 1984, the spending on war against terrorism in Southeastern Anatolia negatively affected the budget balance. Turkey financed the budget deficits by successfully applying the balance policy between foreign exchange rate and interest rate. However, at the end of 1983, when the interest rates were tried to be decreased, the interest rate and foreign exchange rate balance disrupted and economy got closed to a very big crisis. In 1994, when two credit rating agencies decreased the credit rating of Turkey, seven billion USD of hot money outflowed from Turkey. In this environment, the government put a new Stabilization Program into force in April 1994 (Karluk, 2014, p. 526).

\section{April 5th 1994 Stabilization Decisions}

Following the January 24th Decisions, the high real interest rates, the disruption of public balance, and the instability in economy and political structure caused new crisis in economy. The necessity of implementation of a new Stabilization Program occurred because of the increased public deficits, insufficiency of tax incomes to pay the debt services, and State's financing of its cash deficit by internal borrowing. In year 1994, the economy came under the pressure of important internal debt. It was the first time in Turkey's history that State was borrowing 
more from the internal market to pay its foreign debts. In that year, the foreign debts converted to internal debts and internal debts were increasing while payments of the foreign debts were made. In year 1995, 241.5 Trillion TL internal debt interest had to be paid, because of the policy of intense internal borrowing to prevent the raise in foreign currency exchange and to recover the budget deficit during the year 1994. The total internal debt extended to 656 trillion TL, the rate of internal debts reached to $18 \%$ GDP.

The increase in interest rates caused the short term inflow of foreign hot money to the country. The appreciation of TL restrained the exports but facilitated the imports. As a result of this, in year 1993, the international trade deficit became 14 billion USD, while the current account deficit reached to 6.3 USD. In year 1993, first in Republic history, State's internal debt and its interest payments exceeded the total tax income. While these adverse developments were occurring in economy, during the period when Istanbul Stock Exchange (ISE) decreased its interest rates to increase its index, on the day of 13th January 1994, Moody's and in March 1994 Standard and Poor's (S\&P) decreased Turkey's credit scoring to BA2 and BBB so, Turkey became a "risk bearing country for investment" from "investible country". In fact, Moody's, by decreasing the credit scoring of Turkey, ignited the fuse of the crisis (Yeldan, 1998, pp. 397-414). The very first credit score that S\&P gave to Turkey in 1991 was BBB+. With that score, Turkey had exported a Yankee Bond to US market and became one of the countries of investment for USA insurance companies (Kargi, 2014, pp. 351-370; Çalişkan, 2002, pp. 53-66).

Against the movement that has started with the decrease of credit scoring by S\&P and Moody's, the government tried to break the pyramid scheme of people who brings hot money to Turkey by controlling the interest rates. In addition, in order to decrease the budget deficit, the government applied a 5\% stoppage income tax to the security income arising out of securities of Treasury. The Treasury tried to break the pyramid scheme of people earning money from securities; however it has not been successful (Karluk, 2014, pp. 507-542). Since ISE was not deep enough to attract the speculative capital market, before the 5th of April, the money was directed into foreign currency rather than stock. The government consolidated its debts to Central Bank and excessively used the Central Bank's sources. As a result, the situation got heavier. Although the Central Bank to balance the exchange rate, supplied foreign currency to the market, it has not been successful and the fluctuation and ambiguity in foreign currency market continued. In this environment 5th April 1994, dated Stabilization Decisions were taken. The targets of the Decisions were: reducing the inflation, increasing the velocity of exports, and establishing a sustainable economic and social progress by paying attention to the social balance. On one hand, the Decisions targeted the economic stabilization; on the other hand, they targeted the structural reforms to enable the sustainability of the stabilization (DPT, 1994).

The developments that lead to the Decisions were explained as follows in the introduction section of the Decisions: Following the 24th January 1980 dated Economic Stabilization Decisions, especially from the year of 1990, the high increase of public deficit, insufficiency of tax incomes to pay the debt services, State's financing of its cash deficit with internal borrowing, the foreign currency reserves melting down with the State's directing to external debts and State's use of Central Bank resources to recover the deficit lead to the necessity of implementation of a new Stabilization Program.

After 1990, the ratio of PSBR/GNP passed over 10\%. The deficit especially aroused out of public current and transfer expenditures. In addition, for financing, the internal and external borrowing has been used. The increase of total debts also increased the yearly payments of principal and interests. The fast growing public deficit caused an increase in borrowing and internal interest rates. 
The Decisions were neither purely heterodox nor perfectly orthodox. In the Decisions, the exchange rate has been chosen as anchor. In fact, choosing the exchange rate as an anchor leads to the failure of the stabilization program since it decreased the strength of competition which worsens the payment balance. The Decisions are parallel to the stabilization programs that have been implemented in other countries back then and have similarities to the programs implemented in Israel in year 1985. The economic policies that have been implemented in Israel between 1980 and 1981 caused the current deficit and over valuation of the Israel's currency (Kesbiç \& Çevik, 2007, p. 106) as they have been in Latin American countries (Bruno, 1991). This situation, with the movement of capital, leads to a crisis, and Israel had to implement devaluation. Following the devaluation, the inflation rate became $500 \%$ yearly. Even there had been some improvement in current accounts and several foreign supports given (foremost from USA), capital outflow from Israel occurred.

Following the Decisions, although a support has been given to the agricultural product prices, it could not meet the velocity of the inflation so the farmers were damaged. The shrinkage of economic demand combined with the net active tax collected from the income tax and corporate income tax payers, caused the restriction of production in industrial institutions and that triggered the job cuts. As a result of these developments, shrinkage occurred in the real sector. The real sector shrinkage exceeded the shrinkage occurred in years of 1944 and 1949 and recession occurred. The discomfort index, which is calculated by adding inflation and unemployment number, reached to $158 \%$ rate and set a record among OECD countries. In 1994, with the increased inflation and unemployment, the discomfort index which is used to measure the performance of the economy, increased to $65.7 \%$ in 1993 . The index was $57.2 \%$ in $1990,66.5 \%$ in 1990 , and $69.4 \%$ in 1992 . Compared by 10 industrial countries of the world, Turkey became the very last in the list. The average discomfort index of these 10 countries is $11.2 \%$ and Turkey's index number was 14 times worse (OECD, 1995).

Examining the period of 1923-1994, the year of 1994 was the year of recession. This phenomenon was affected by the unrestricted public spending and undermining of the enhancement of the public income. The deviation from the inflation target caused the evaporation of the essence of the Decisions. Even with all the suffering, the targeted inflation was not met, so disturbance in society aroused. IMF requested the targeted inflation to be met since inflation was anchor of the support arrangement. The deviation for this target prevented the realization of other targets.

The measures could not prevent the demand for foreign currency, the structure of banking sector disrupted and three banks (Marmara Bank, TYT Bank, and Impex Bank) bankrupted. The Ekspres Bank changed hand, the rush to banks has been prevented by giving unlimited State guarantee on savings deposits. The government, in order to try to decrease the interest rates, borrowed money with very high interest rates (the highest of Republic history). The three months due Treasury bonds were exported with 50\% (yearly compound interest 406\%) net income. In year 1994, economy downsized to 6.1\% (Karluk, 2014, p. 546). The created income decreased to 132 billion USD (2.184 USD per person) in 1994 from 173 billion USD (2.883 USD per person) in 1993.

In summary, the 5th April Decisions were more successful in financial markets and public economy. TL earned stabilization with the increased demand, the Treasury recovered its debts by internal borrowing. The internal borrowing interests decreased, the SOEE's financial structure improved with price increases and the money markets started to operate over again. The Decisions, although partially reached their targets, could not provide the structural changes and stabilization in economy (Toprak, 1996, pp.174-193). The 1994 crisis was the worst historical crisis in Republic history. Turkey exited from this crisis, by increasing its interest rates to three digits numbers from $80 \%$ and by undertaking the risks of all bank deposits in the banking system. 
The crisis brought Turkey in a situation again in need of IMF. After 1985, there was no need for the IMF sources, however in year 1994, a new IMF support arrangement had to be made. In 1994, with the 4,050 numbered Law, an additional budget of 100 trillion TL put into effect, the consolidated budget converted to transfer and current expenditure budget, the investment payments could not meet the amortizations, the public production investment decreased to minimum levels. The Decisions and arrangements were unsuccessful, so IMF declared Turkey as unsuccessful country in privatization (Türkan, 1996, pp. 230-236). Although the Decisions include extensive arrangements from short-term policy measures to structural reforms, with the effect of internal and external pressures, the letter of intent included government's aspirations. The 5th April Decisions which was tried to be implemented by back then Prime Minister Tansu Çiller, passed into history as a collection of unsuccessful measures, having populist predominance (Toprak, 1996, pp. 174-193).

\section{The Conclusion}

Even it is hard to prevent the effect of global crisis, in Turkish economy, since 1946, in order to prevent the crisis, importance was especially given to the payments balance because, in Turkey and other liberal economies, most of the crises were foreign currency based crises (Dornbusch, Goldfajn, \& Valdes, 1995, pp. 219-293; Öztürk, 2015, p. 433). In order to establish a healthy payment balance, the macroeconomic policies and short term capital movements should be regarded. In developing countries such as Turkey, the crises are caused by external imbalances. Prevention of this effect could be realized by changing the economic structure. Without any structural economic changes, it is inevitable to prevent the persistence of crises.

The year 1980 was a year of structural economic changes in Turkish economy. After this year, the globalization concept in global economy affected the Turkish economy as well as economies of other countries. The countries adopted liberal policies and started to give importance to the extroverted industrialization and liberalization policies. Since then, these policies have been continuing. In Turkish economy, from year 1946 to present, there have been foreign currency and payments crises, also financial and real sector crises. The stabilization decisions were taken to prevent the 1958, 1970, and 1980 crises. As a result of the frequent crises experienced after the year 1980, the accelerating inflation has been in the economic agenda of Turkey for a long period of time. In times of crises, with a few exceptions, the stabilization programs supported by IMF have been implemented. In order to implement the structural transformation and to overcome the crises occurred before year 1980, 24th January 1980 Decisions were taken.

One of the important indicators to measure the success of the stabilization decisions is the fluctuations in national income. The ratio of GNE to GDP fluctuated widely in the years that the decisions were implemented (Table 1). In the years of 1980-2000, there was an increase in GNE/GDP but in some other years, sudden declines were observed. This situation created the environment for crises. Since the 1980 Decisions, until today, although the GNE/GDP increased, a stabilized economic growth has not been realized. In this period, although the production structure changed against the agricultural sector, the targeted sector structure of GNE/GDP has not been realized. However, after 1980, the exports increased and an alteration has been realized in structure of exports in favor of industrial products. By the imports regime that has been put in implementation in 1984, the customs and consumption tax on most of the products were decreased. After 1980 in Turkish economy, the external debt increased and 20 billion USD debt stock in 1980 reached to 49 billion USD in 1990, 73 billion USD in 1995, 115 billion USD in 2000 and the maturity structure disrupted (Öztürk \& Özyakişir, 2005). 
Table 1

The Development of GNE/GDP in Years (1980-1995)

\begin{tabular}{lll}
\hline Years & The value of GNE (billion $\$)$ & The rate of growth $(\%)$ \\
\hline 1980 & 50.870 & -2.8 \\
1985 & 63.989 & 4.3 \\
1990 & 84.592 & 9.4 \\
1991 & 84.887 & 0.3 \\
1992 & 90.323 & 6.4 \\
1993 & 97.677 & 8.1 \\
1994 & 91.733 & -6.1 \\
1995 & 99.028 & 8.1 \\
\hline
\end{tabular}

Source: DIE (2015a; 2015b; 2015c; 2015d), Turkey Statistics Yearbook, several issues; DTM (2015), The Turkish Economy from 1923 to Present.

Table 2

The Development in External Debt Stock (1984-1995)

\begin{tabular}{llll}
\hline Years & Total external debt (billion USD) & Medium and long term (\%) & Short term (\%) \\
\hline 1984 & 20.65 & 17.47 & 3.18 \\
1990 & 49.03 & 39.53 & 1.79 \\
1995 & 73.27 & 57.57 & 15.58 \\
\hline
\end{tabular}

Source: DIE (2015a; 2015b; 2015c; 2015d), Turkey Statistics Yearbook, several issues.

During the international expansion of the economy, in order to straighten the defected areas, a central interference could be needed. In words of Yenal (1999, p. 164): "We may think of environments that a central interference is needed in situations that the liberal market wisdom fails". After 1990s, as a result of public internal and external borrowings and melted foreign currency reserves, new stabilization decisions were needed to be taken. The crises occurred in 1997 in Asia, 1998 in Russia together with the earthquake in 1999 August, Turkey faced new crises in 2000 November and 2001 February. The major determinant of these crises was the liquidity crisis in banking sector (Eroğlu \& Aydin, 2015, p. 466).

In London, in 2009, Recep Tayyip Erdoğan, the Prime Minister of that period, in his speech having the topic of "The Global Crisis and Role of Turkey" at The Royal Institute of International Affairs, Chatham House, stated that "Some got disturbed when I have told that this crisis has passed tangent to Turkey. I insist on the same words. 'Passed tangent' does not mean unaffected. There is a friction, ablation margin, however it least affects us". However, stabilization could not be realized in economy. In last seven years, no economic crisis has been experienced in Turkey. The target of growth has been stated in 2016-2018 Medium Term Program. However, the target of growth with structural reforms in an environment of macroeconomic stability and reduced current deficit and inflation has not been realized yet.

By the 24th January Decisions, the Turkish economy has changed its shell. A door to provide integration of Turkish economy to global economy has been opened with a new economic policy of free market perspective which is based on profit maximization and competitive price policy. If the 24th January Decisions were not taken, it would not be possible to complete the integration with Customs Union in 1996 and the integration with European Union would not have been realized. Turkey has accomplished the international expansion in 1980. However, based on the fundamental macroeconomic indicators, Turkey has not been able to realize the desired 
stabilization, and not been successful in reaching the goals of the stabilization programs. As expressed by Rodrik (1990), in his words "a premature liberalization" was realized with 24th January Decisions.

\section{References}

Akalin, G. (2002). Türkiye'de piyasa ekonomisine Geçiş Süreci ve ekonomik Kriz. Ankara: TISK Yayinlari.

Alkan, S., \& Bahçekapili, C. (1998). Iktisadi Krizler-IMF Politikalari Ilişkisi ve Finance and Development Dergisindeki Yansimalari. Iktisat, Işletme ve Finans Dergisi, Yil:13, Sayi:144, Istanbul.

Bahçeci, A. S. (1997). Ortodoks ve Heterodoks Istikrar Programlari: Seçilmiş Ülke Örnekleri ve 1994 Türkiye Deneyimi. DPT EMSAGM, Ankara.

Boratav, K. (2010). Türkiye Iktisat Tarihi (1908-2007). Ankara: Imge Kitapevi.

Boratav, K., Keyder, Ç., \& Pamuk, Ş. (1984). Krizin Gelişimi ve Türkiye’nin Alternatif Sorunu. Istanbul: Kaynak Yayinlari.

Bruno, M. (1991). Introduction and overview. In M. Bruno, S. Fischer, E. Helpman, and N. Liviatan (Eds.), Lessons of economic stabilization and its aftermath (p. 10). London: MIT Press.

Cin, M. F., Yalçin, B. K., \& Doğru, M. K. (2000). Heterodoks Politikalar Işiğinda Türkiye’de Uygulanmakta Olan Istikrar Programi ve Bir Değerlendirme. Istanbul Üniversitesi Siyasal Bilgiler Dergisi, sayi 23-24, pp. 65-90.

Çalişkan, Ö. V. (2002). Kredi derecelendirme kuruluşlari ve risk değerlendirme kriterleri. Gazi Üniversitesi IIBF Dergisi, 1, 53-66. Retrieved from file://C:/Users/srkarluk/Downloads/397-783-1-SM\%20(2).pdf 25.12.2015

Çarikçi, E. (1983). Yarigelişmiş Ülkelerde ve Türkiye'de Sanayileşme Politikalari. Ankara: Turhan Kitabevi.

DIE. (2005a). Diş Ticaret Istatistikleri Temmuz/2005. Tetrieved http://www.die.gov.tr/TURKISH/SONIST/DISTICIST/disticist.html 15.11.2015

DIE. (2005b). Istatistikler/Göstergeler. Retrieved from http://www.die.gov.tr/gostergeler.htm

DIE. (2005c). Diş Ticaret Istatistikleri. Retrieved from http://www.die.gov.tr/TURKISH/SONIST/DISTICIST/disticist.html

DIE. (2005d). Türkiye Istatistik Yilliği. Retrieved from http://www.die.gov.tr/yillik/yillik_2004.pdf

Dibooglu, S., \& Kibritcioglu, A. (2004). Inflation, output growth, and stabilization in Turkey, 1980-2002. Journal of Economics and Business, Elsevier, 56(1), 43-61.

Dornbusch, R. (1992). Lessons from experiences with high inflation. World Bank Economic Review, 6(1), 13-31.

Dornbusch, R., \& Fisher, S. (1993). Moderate inflation. The World Bank Economic Review, 7, 1-44. Retrieved from http://www.nber.org/papers/w3896.pdf. 22.12.2015

Dornbusch, R., Goldfajn, I., \& Valdes, R. O. (1995). Currency crises and collapses. Brookings Papers on Economic Activity, 2, 219-293. Retrieved from http://www.brookings.edu/ /media/Projects/BPEA/1995-2/1995b_bpea_dornbusch_goldfajn_ valdes_edwards_bruno.PDF

DPT. (1994). Ekonomik Önlemler Uygulama Paketi. Ankara: DPT Yayini.

DTM. (2005). 1923'den Günümüze Türkiye Ekonomisi. Retrieved from http://www.dtm.gov.tr/Ekonomi/Trkekon.htm. 17.12.2016

Eğilmez, M., \& Kumcu, E. (2013). Ekonomi Politikasi ve Teori ve Türkiye Uygulamasi. Istanbul: Remzi Kitabevi.

Ekzen, N. (1984). 1980 Stabilizasyon Paketinin 1958, 1970 ve 1978-1979 Paketleri ile Karşilaştirmali Analizi. In I. Tekeli (Ed.), Türkiye'de ve Dünyada Yaşanan Ekonomik Bunalim (p. 1275). Ankara: Yurt Yayinevi.

Eroğlu, I., \& Aydin, I. (2015). 1994 Krizi Sonrasi Dönem ve Kasim 2000 Yili Mali Krizi. In N. Eroğlu (Ed.), Iktisadi Krizler ve Türkiye Ekonomisi (pp. 465-476). Ankara: Orion Yayinevi.

Ertuna, Ö. (2001). Türkiye'de ekonomik krizler, nedenleri ve çikiş yolu. Yeni Türkiye Dergisi, Eylül-Ekim Ekonomik Kriz Sayisi, 41, 491-510.

Esen, O. (1989). Heterodoks Istikrar Programlari: Teori ve Uygulama. ODTÜ Gelişme Dergisi, 16(3-4), 33-64.

Hakan, E. (2000). Açik ekonomi, ıstikrar tedbirleri ve sicak para: Türkiye. Ankara: MPM Yayinlari. HÜRRIYET, 10.11.1977, 03.09.2000, 04.10.2000, 19.03.2002.

Helpman, E., \& Leonardo, L. (1988). Stabilization in high inflation countries: Analytical foundations and recent experience. Carnegie Rochester Conference Series on Public Policy, No. 28, pp. 9-84.

Kargi, B. (2014). Uluslararasi Kredi Derecelendirme Kuruluşlari ve Türkiye'nin Kredi Notu Üzerine Bir Inceleme (1998-2013). The Journal of Academic Social Science Studies, 7(1), 351-370. Retrieved from https://mpra.ub.uni-muenchen.de/55698/ 21.02.2016

Karluk, S. R (2014). Türkiye ekonomisi. Istanbul: Beta Basim.

Karluk, S. R. (1981). Türkiye’ de Ihracata Yönelik Diş Ticaret Politikasi ve Ihracatin Yapisal Analizi. Eskişehir: ITIA Basimevi. 
Karluk, S. R. (2010). Turgut Özal'in Ekonomi Politikalari Kapsaminda Krizlere Karşi Uygulamaya Koyduğu Ekonomi Politikalari. Turgut Özal Uluslararasi Ekonomi ve Siyaset Kongresi-I: Küresel Krizler ve Ekonomik Yönetişim, 16 Nisan 2010, Malatya.

Karluk, S. R. (2013). Uluslararasi ekonomi. Istanbul: Beta Basim.

Karluk, S. R. (2015). Türkiye Ekonomisinde Kasim 2000-Şubat 2001 Krizleri ve Krizleri Önlemeye Yönelik Ekonomik Istikrar Kararlari. In N. Eroğlu (Ed.), Iktisadi Krizler ve Türkiye Ekonomisi (pp. 477-502). Ankara: Orion Yayinevi.

Kesbiç, C. Y., \& Çevik, M. (2007). Döviz Kuruna Dayali Istikrar Politikalarinin Enflasyon Üzerindeki Etkisi: Türkiye Ekonomisi Için Bir Model Denemesi. Süleyman Demirel Üniversitesi IIBF Dergisi, 12(1), 95-116. Retrieved from http://sablon.sdu.edu.tr/fakulteler/iibf/dergi/files/2007-1-6.pdf

Kibritçioğlu, A. (2001). Türkiye'de Ekonomik Krizler ve Hükümetler, 1969-2001. Yeni Türkiye Dergisi, Ekonomik Kriz Özel Sayisi, 7(41), 174-182. Retrieved from http://80.251.40.59/politics.ankara.edu.tr/kibritci/ytd-kibritcioglu.pdf

Kibritçioğlu, A. (2015). 2008 Küresel Finansal Krizi Öncesi Krizler ve Türkiye Ekonomisi. In N. Eroğlu (Ed.), Iktisadi Krizler ve Türkiye Ekonomisi (pp. 504-518). Ankara: Orion Yayinevi.

Kiguel, M. A., \& Liviatan, N. (1991). Lessons from the heterodox stabilization programs. World Bank Working Papers. Retrieved from https://books.google.com.tr/books?id=3yHUmxjRHK0C\&pg=PP2\&lpg=PP2\&dq=\%E2\%80\%9CLessons+from + the + Heterod ox + Stabilization+Programs $\%$ E2\% $\% 0 \%$ D, ++ World+Bank,+Working+Papers: $+671 . \&$ source=bl\&ots=wJAf1 xSvH6\&sig=D1 Vh2ZOApLCZZSWWavlxf6iMR5A\&hl=tr\&sa=X\&ved=0ahUKEwij87-jwtvKAhXHjSwKHeuUDEkQ6AEIJjAB\#v=onepa ge \&q $=\%$ E2 $\% 80 \% 9$ CLessons $\% 20$ from $\% 20$ the $\% 20$ Heterodox $\% 20$ Stabilization $\% 20$ Programs $\%$ E2 $\% 80 \% 9 \mathrm{D} \% 2 \mathrm{C} \% 20 \% 20 \mathrm{Wo}$ rld\%20Bank\%2C\%20Working\%20Papers\%3A\%20671.\&f=false

Kumcu, E., \& Pamuk, Ş. (2001). Artik herkes milyoner. Istanbul: Doğan Kitap.

Kuruç, B. vd. (1987). Birakiniz Yapsinlar, Birakiniz Geçsinler Türkiye Ekonomisi 1980-1985. Ankara: Bilgi Yayinevi.

OECD. (1995). Economic Surveys: Turkey 1995. Paris.

Öztürk, N. (2015). 1994 Krizine Yeniden Bakmak. In N. Eroğlu, vd. (Ed.), Iktisadi Krizler ve Türkiye Ekonomisi (pp. 433-464). Ankara: Orion Yayinevi.

Öztürk, S., \& Özyakişir, D. (2005). Türkiye Ekonomisinde 1980 Sonrasi Yaşanan Yapisal Dönüşümlerin GSMH, Diş Ticaret ve Diş Borçlar Bağlaminda Teorik Bir Değerlendirmesi. Mevzuat Dergisi, 94 . Retrieved from http://www.mevzuatdergisi.com/2005/10a/01.htm

Parasiz, I. (1998). 1923'den Günümüze Iktisat ve Istikrarin Politikalari. Bursa: Ezgi Kitabevi.

Rodrik, D. (1990). Premature liberalization, incomplete stabilization: The Ozal Decade in Turkey. NBER Working Paper, No. 3300: 3. Retrieved from http://www.nber.org/papers/w3300.pdf

Şenses, F. (1981). Short term stabilization policies in a developing economic: The Turkish experience in 1980 in long term perspective. ODTÜ Gelişme Dergisi, 8(1-2), 417.

TIM. (1996). Türkiye'de Enflasyon. Istanbul: Türkiye Ihracatçilar Meclisi Yayinlari.

Tokgöz, E. (2001). Türkiye'nin Iktisadi Gelişme Tarihi. Ankara: Imaj Yayinevi.

Toprak, M. (1996). Türk Ekonomisinde Yapisal Dönüşümler: 1980-1995. Ankara: Turhan Kitabevi.

Turan, Z. (2011). Dünyadaki ve Türkiye'deki Krizlerin Ortaya Çikiş Nedenleri ve Ekonomik Kalkinmaya Etkisi. Niğde Üniversitesi IIBF Dergisi, 4(1), 56-80.

Türkan, E. (1996). Ekonomi ve Demokrasi. Ankara: Turhan Kitabevi.

Uludağ, I., \& Serin, V. (1987). Diş Şoklara Karşi Dünya'da ve Türkiye'de Geliştirilen Istikrar Politikalari. Istanbul Ticaret Odasi Yayinlari, Istanbul.

Uygur, E. (1993). Enflasyonun Aktörleri, Faktörleri ve Anti-Enflasyonist Politikalar. Işletme ve Finans Dergisi, 8(91), 6-38.

Wijnbergen, S. V. (1987). Fiscal deficits, exchange rate crises and inflation. NBER Working Paper Series, No.2130. Retrieved from http://www.nber.org/papers/w2130.pdf

Yazgan, E., \& Akay, K. (2000). Kura Dayali Istikrar Politikalari: Teori ve Uygulama. Bahçeşehir Üniversitesi Ekonomi ve Yönetim Bilimleri Dergisi, 1(2), 47-74.

Yeldan, E. (1998). On structural sources of the 1994 Turkish crisis: A CGM modeling analysis. The International Review of Applied Economics, 12(3), 397-414.

Yeldan, E. (2003). Küreselleşmenin Neresindeyiz? Türkiye Ekonomisinde Borç Sorunu ve IMF Politikalari. Retrieved from http://www.stradigma.com/turkce/kasim2003/makale_06.html

Yenal, O. (1999). Iktisat Siyasasi ve Plan. Iktisat Siyasasi Üzerinde Incelemeler, Türkiye Iş Bankasi Kültür Yayinlari, 29, Ankara. 